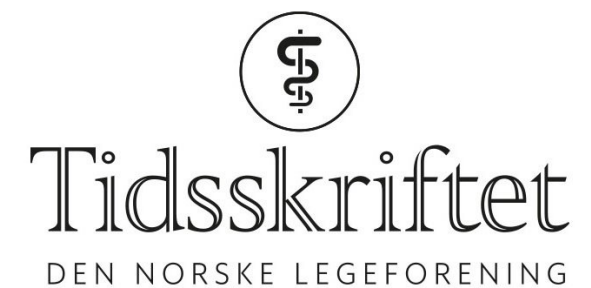

DEN NORSKE LEGEFORENING

\title{
Kunstig intelligens vil endre helsetjenesten
}

LEDER

\section{KLAS H. PETTERSEN}

E-post: klas.pettersen@nora.ai

Klas H. Pettersen er sivilingeniør i fysikk, ph.d. i teoretisk nevrovitenskap og daglig leder for Norwegian Artificial Intelligence Research Consortium (NORA), et samarbeidsnettverk mellom flere norske universiteter og andre forskningsmiljøer om kunstig intelligens, maskinlæring og robotikk. Forfatteren har fylt ut ICMJE-skjemaet og oppgir ingen interessekonflikter.

«Vi står overfor et paradigmeskifte på linje med da hesten ble erstattet av bil.»

Dette sa Erik Fosse i forbindelse med at Stortingsmeldingen om helsenæringen (1) ble fremlagt i april. Fosse beskrev den teknologiske utviklingen i operasjonssalen og hvordan teknologiseringen av helsevesenet har ført til økt kvalitet på pasientbehandlingen. Utviklingen innen radiologi, genetikk, sensorteknologi og en rekke andre områder muliggjør innsamling av enorme mengder pasientdata. Dette gir sikrere diagnoser og er fundamentet for skreddersydde behandlinger. De enorme datamengdene vi kan høste, kombinert med økt mulighet for persontilpasset behandling, gjør at vi står overfor et paradigmeskifte. Høy kompleksitet og overveldende datamengder vil føre til at kunstig intelligens får en sentral rolle i fremtidens helsevesen.

En myteomspunnet workshop på Dartmouth College i 1956 regnes som fødselen for kunstig intelligens som akademisk disiplin (2). Feltet er med andre ord ikke nytt, men $\emptyset \mathrm{kt}$ regnekraft, økt tilgang til store datamengder og stadig bedre læringsalgoritmer har gitt en kraftig oppblomstring av underkategorien maskinlæring (eng. machine learning). Samlet forskningsaktivitet for maskinlæring brukt innenfor medisin reflekterer dette. Før år 2000 var det typisk fra null til litt over tjue årlige publiseringer indeksert i PubMed, for 2018 var tallet 5491 - utvikling viser en eksponentiell vekst med en dobling cirka hvert 2,5 år i løpet av perioden. På samme måte har dyplæring (eng. deep learning) hatt en eksplosiv vekst fra år 2013.

Det er innen bildegjenkjenning dyplæring har hatt spesielt gode resultater, og dyplæring er allerede på vei inn i klinisk virksomhet

Dyplæring, som er en underkategori av maskinlæring, er basert på kunstige nevrale nettverk hvor strukturen er inspirert av hjernen. Kunstige nevroner er koblet sammen gjennom synapser, og når nettverket lærer, endres synapsenes styrke. I sin enkleste form fungerer disse kunstige nevronene som prosesser som mottar signaler fra mange andre kunstige nevroner, summerer all input og skrur seg på dersom summen er større enn en gitt terskelverdi. Kunstige nevrale nettverk har et input-lag, et output-lag og flere skjulte lag 
av nevroner, og nettverket kalles dypt dersom det er flere enn ett skjult lag. Med økt regnekraft og økt tilgang til data har nettverkene de senere årene blitt stadig bedre og stadig dypere. Eksempelvis er et nettverk som kan gjenkjenne pneumoni fra røntgenbilder, CheXNet (3), 121 lag dypt.

Det er innen bildegjenkjenning dyplæring har hatt spesielt gode resultater, og dyplæring er allerede på vei inn i klinisk virksomhet. I 2018 ble et verktøy for å oppdage diabetisk retinopati godkjent av U.S. Food and Drug Administration (FDA) som det første autonome systemet for kunstig intelligens innen diagnostisk medisin (4). Nå er det flere enn 30 FDAgodkjente algoritmer for kunstig intelligens, og listen med artikler hvor dyplæring har gjort bildediagnostikk like godt eller bedre enn erfarne leger, er lang. Artikler som har gått gjennom fagfellevurdering, inkluderer blant annet temaer som brystkreft, lungekreft, hjernetumor, hudkreft, melanom, polypper (koloskopi) og EKG (5). Ikke uventet viser flere av disse studiene at det er når man kombinerer kunstig intelligens med erfarne radiologer, man får best prediksjon.

Med bruk av kunstig intelligens følger det flere store utfordringer. Som hjernen kan også kunstig intelligens være forutinntatt (med bias) og ofte lite gjennomsiktig (en black box). Bias er en praktisk konsekvens av utilstrekkelige og ikke-representative treningsdata, noe man må være oppmerksom på når treningsdata samles og kureres. Black boxproblematikken er imidlertid mer fundamental. Beslutningsgrunnlaget til et dypt nettverk kan være ekstremt komplekst og ofte i praksis umulig å forstå. I mange tilfeller er black boxbeslutninger utilfredsstillende, og det oppstår et dilemma hvis en svært treffsikker algoritme gjør klassifiseringer eller kommer med råd som strider mot menneskelig intuisjon eller forståelse.

Som hjernen kan også kunstig intelligens være forutinntatt og ofte lite gjennomsiktig

Kroppsbåren teknologi som Apple Watch, som er FDA-godkjent for deteksjon av atrieflimmer, kombinert med kunstig intelligens gjør det mulig å gjennomføre automatisk deteksjon av uregelmessigheter i stor skala. En slik demokratisering av helsedata kan fange opp alvorlige sykdommer, øke befolkningens helsebevissthet og gi stor helsegevinst, men det kan også føre til store mengder falske positive funn og dermed unødvendige konsultasjoner for den friske delen av befolkningen.

Bruk av kunstig intelligens innenfor helsesektoren ligger i startgropen, men kommer til å bli særdeles viktig i helsevesenet i fremtiden. I Norge har vi en høy grad av digitalisering, store mengder registerdata og gode informatikkmiljøer. Vi har dermed et godt grunnlag for grunnleggende forskning, utvikling og bruk av kunstig intelligens, og konsortiet Norwegian Artificial Intelligence Research Consortium (NORA) er opprettet for å samordne forskning på feltet. Skal vi lykkes, må vi i større grad koble grunnforskning, algoritmer og teknologiutvikling med konkrete problemstillinger fra helsesektoren og andre samfunnsområder, på tvers av den tradisjonelle fakultetsstrukturen og på tvers av norske universiteter og forskningsinstitusjoner.

LITTERATUR:

1. Meld. St. 18 (2018-2019) Helsenæringen - Sammen om verdiskaping og bedre tjenester.

2. Moor J. The Dartmouth College Artificial Intelligence Conference: The Next Fifty years. AI Mag 2006; 27: 87-9.

3. Rajpurkar P, Irvin J, Zhu K et al. CheXNet: Radiologist-Level Pneumonia Detection on Chest X-Rays with Deep Learning. arXiv:1711.05225v3

4. Abràmoff MD, Lavin PT, Birch M et al. Pivotal trial of an autonomous AI-based diagnostic system for detection of diabetic retinopathy in primary care offices. NPJ Digit Med 2018;1:39. [PubMed][CrossRef] 5. Topol EJ. High-performance medicine: the convergence of human and artificial intelligence. Nat Med 2019; 25: 44-56. [PubMed][CrossRef] 
Publisert: 2. oktober 2019. Tidsskr Nor Legeforen. DOI: 10.4045/tidsskr.19.0479

(C) Tidsskrift for Den norske legeforening 2020. Lastet ned fra tidsskriftet.no 